\title{
Predictive value of intravenous glucose tolerance test insulin secretion less than or greater than the first percentile in islet cell antibody positive relatives of Type 1 (insulin-dependent) diabetic patients
}

\author{
P. $\operatorname{Vardi}^{1}$, L. Crisa ${ }^{1}$, R. A. Jackson ${ }^{1}$ and coauthors (see acknowledgments) $)^{2,3,4,5,6}$ \\ 1 Joslin Diabetes Center, Brigham and Women's Hospital, New England Deaconess Hospital, and Harvard Medical School, Boston, \\ Massachusetts, ${ }^{2}$ University of California, Davis, Sacramento, ${ }^{3}$ Diabetes and Endocrine Associates, San Diego, California, \\ ${ }^{4}$ Diabetes Center of Excellence, Humana Hospital, Mesa, Arizona, ${ }^{5}$ New England Diabetes and Endocrine Center, Chestnut Hill, \\ Massachusetts, and ${ }^{6}$ Pediatric/Adolescent Diabetes Center, Morristown, New Jersey, USA
}

\begin{abstract}
Summary. We have followed-up 35 islet cell antibody-positive first degree relatives of patients with Type 1 (insulindependent) diabetes mellitus for an average of 1,300 days with sequential intravenous glucose tolerance tests. At the time of analysis and manuscript submission approximately half (18 of 35$)$ had developed diabetes during follow-up. At initial intravenous glucose tolerance test, 11 had a $1+3 \mathrm{~min}$ insulin secretion below the first percentile of insulin secretion compared to 225 similarly studied normal control subjects. Six islet cell antibody positive relatives on follow-up developed an intravenous glucose tolerance test less than the first percentile. Fifteen out of $17(88 \%)$ of these islet cell antibody positive relatives with secretion ever found to be below the first percentile are now overtly diabetic (positive predictive value $=88 \%$ ) and insulin-treated, while only 3 of 18 $(17 \%)$ without an intravenous glucose tolerance test demonstrating loss of first phase insulin secretion have progressed to diabetes (with approximately 1,300 days of follow-up for both groups relative risk or odds ratio with intravenous glucose tolerance test ever below vs never below the first per-
\end{abstract}

centile $=38, p<0.001$ ). Intravenous glucose tolerance test response below the first percentile preceded diabetes by an average of 656 days. Even when first phase insulin secretion is below the first percentile, the absolute value of $1+3 \mathrm{~min}$ insulin above basal insulin correlates with the time to development of diabetes $(r=0.586, p<0.001)$. With our current duration of follow-up, the negative predictive value (intravenous glucose tolerance test never below the first percentile) is $83 \%$, and overall accuracy $86 \%$. Incidence rates of diabetes development amongst our islet cell antibody positive relatives with follow-up while intravenous glucose tolerance test is below the first percentile is 0.48 per year $(15$ conversions to diabetes amongst 17 relatives in 30.8 patient years of follow-up) vs 0.05 per year (three diabetic patients in 55.5 patient years) with intravenous glucose tolerance test greater than the first percentile.

Key words: Intravenous glucose tolerance test, islet cell antibodies, prediction.
With less than seven years of average follow-up and utilizing "high titre" cytoplasmic islet cell antibody assays (ICA), approximately $8 \%$ per year of ICA positive relatives of patients with Type 1 (insulin-dependent) diabetes develop overt diabetes [1-3]. We have reported that abnormalities of 1st phase insulin secretion in response to intravenous glucose can precede Type 1 diabetes in both cytoplasmic islet cell antibody positive and negative relatives [2, 4-6]. In addition to our studies of intravenous glucose tolerance testing (IVGTT) three other centres have evaluated this test in a significant number of ICA positive relatives. Chase and co-workers have reported that insulin secretion (sum of $1+3 \mathrm{~min}$ insulin after intravenous glucose) less than $25 \mu \mathrm{U} / \mathrm{ml}$ in ICA positive children is shortly followed by overt diabetes while none of the similarly defined ICA positive adult relatives progressed to diabetes [7]. Riley and co-workers have suggested that IVGTT response in their family studies is variable and a more quantitative assessment of this parameter in predicting diabetes is necessary [8]. Gale and Bottazzo have indicated in a recent review that IVGTT response below the 1st percentile is usually accompanied by abnormal glucose tolerance [9]. These latter centres have recently introduced IVGTT studies into their prospective evaluation. In our studies of the IVGTT response of 35 ICA positive relatives we now have a mean follow-up period of approximately 1,300 days with 18 individuals progressing to overt diabetes. This study quantitates the predictive value of IVGTT assessment in the ICA positive relatives we have evaluated. 
Table 1. Subsequent development of overt diabetes in islet cell antibody positive relatives

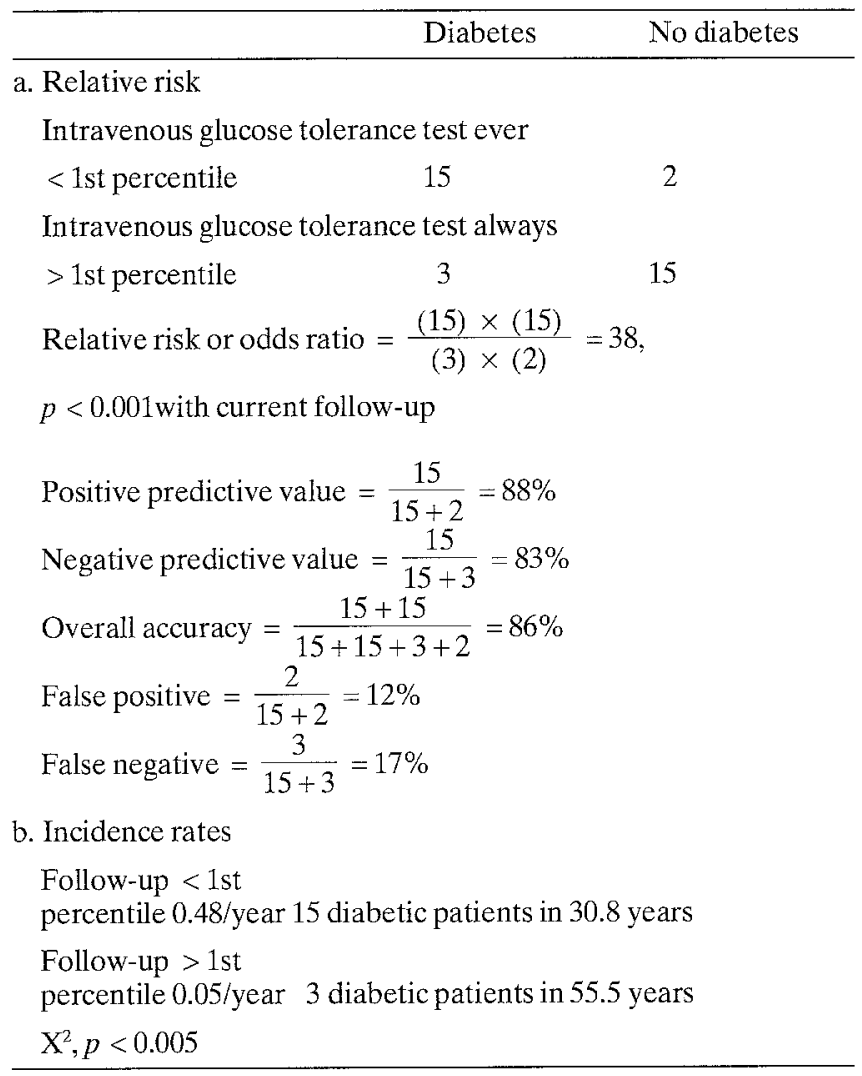

\section{Subjects and methods}

Thirty-five non-diabetic non-obese 1 st degree relatives of patients with Type 1 diabetes (age range at the 1st encounter 2.6 to 66 years, mean $=24.1$ years) were sequentially studied. Criteria for inclusion was ICA-positivity by our protein A assay ( $\geq 40 \mathrm{JDF}$ units) [10], no symptoms or evidence (fasting glucose, $\mathrm{HbA}_{1 c}$, and where available oral glucose tolerance or IVGTT) of diabetes at the time of initial screening (except for patient one where the diagnosis of diabetes was missed in that fasting glucose levels were not analysed until after overt diabetes) greater than one year of follow-up at time of analysis and agreeing to have and having at least one IVGTT prior to the diagnosis of overt diabetes. Thirty of the 35 patients were identified and prospectively followed because of ICA positivity on family screening. First degree relatives of patients with Type 1 diabetes were screened who had been contacted through the Joslin Diabetes Center or collaborating physicians, or who responded directly to a mailed appeal to Joslin patients or an advertised (e.g., Countdown) description of the study. No remuneration for participation in screening was offered but screening and follow-up were provided free of charge. Five patients (reported previously [2]) had been prospectively endocrinologically studied before availability of ICA testing because they were relatives of a Type 1 diabetic patient (nos. 3, 4, 5,9 and 13) and ICA positivity was subsequently identified using frozen sera samples. All subjects were prospectively followed for Beta-cell function, assessed by evaluating blood glucose and insulin secretion. In years 1973, 1978, 1980,1981 and 1983 one relative each year developed overt diabetes, two developed diabetes in 1985, two in 1986, seven in 1987 and two in 1988 (reflecting the 1984 to present expansion of our ICA screening programme). Overt diebetes was diagnosed by the occurrence of a fasting venous plasma glucose $>7.8 \mathrm{mmol} / \mathrm{I}$ or symptomatic hyperglycaemia, with glucose $>11.2 \mathrm{mmol} / \mathrm{l}$ and the institution of insulin therapy. All individuals identified as diabetic have received continuous insulin therapy and are currently insulin treated.

\section{Islet cell antibody assay}

Sera stored at $-20^{\circ} \mathrm{C}$ were tested for islet cell antibodies by indirect immunofluorescence with frozen sections of human pancreas utilizing fluorescein isothiocyanate protein A [10]. The assay utilized is positive in less than $1 / 400$ Framingham population controls, $2 \%$ of 1 st degree relatives of Type 1 diabetic patients [6] and has a detection limit of approximately 40 JDF units [11]. Sera is tested undiluted in a blinded fashion and scored from negative to ++++ . Values reported represent duplicate readings over time for each individual (sera samples are repeated in separate assays to confirm positivity). In an identical manner ICA negative monozygotic twins and HLA identical siblings have been evaluated over time and have been ICA negative on multiple readings (data not shown).

\section{Intravenous glucose tolerance test}

Intravenous glucose tolerance was tested by infusing dextrose $0.5 \mathrm{~g}$ per $\mathrm{kg}$ of body weight to a 20 to $25 \%$ solution over a period of 2 to 4 min. Blood samples were collected before $(0 \mathrm{~min})$ and $1,3,5,10$, $20,30,40,50$ and $60 \mathrm{~min}$ after the end of the rapid intravenous infusion and were assayed for glucose with a Beckman glucose analyzer and reported as plasma glucose in $\mathrm{mg} / 100 \mathrm{ml}$ (to convert to $\mathrm{mmol} / 1$ multiply by 0.056 ) and insulin by a standardized and quality controlled double antibody radioimmunoassay.

The sum of $1+3$ min insulin values were used as an index of the early phase insulin response, and the results were expressed as a percentile of the response in 225 non-obese normal individuals with no family history of diabetes (age range 8 to 77 years). The normal individuals included Joslin Diabetes Center researchers and relatives. All IVGTTs were performed after a $10 \mathrm{~h}$ overnight fast on outpatients who were instructed to consume at least $200 \mathrm{~g}$ of carbohydrate per day for three days prior to testing. The 1 st percentile of insulin release of these normal subjects expressed as the sum of $1+3 \mathrm{~min}$ insulin is $48 \mu \mathrm{U} / \mathrm{ml}$ (3rd percentile $=56 \mu \mathrm{U}$, 5th percentile $=64 \mu \mathrm{U}, \quad 10$ th percentile $=81 \mu \mathrm{U}$ and 50 th percentile $=$ $162 \mu \mathrm{U} / \mathrm{ml}$ ). Percentiles for $1+3 \mathrm{~min}$ insulin subtracting twice the fasting (basal) insulin in the same control population is: 1st percentile $=24 \mu \mathrm{U}, 3 \mathrm{rd}$ percentile $=33 \mu \mathrm{U}$, 5th percentile $=43 \mu \mathrm{U}, 10$ th percentile $=55 \mu \mathrm{U}$ and 50 th percentile $=137 \mu \mathrm{U}$. Glucose disposal on IVGTT was expressed as the K-rate. K-rate percentiles in our 225 normal control subjects are 50 th $=2.27,10$ th $=1.41,5$ th $=1.24$, $3 \mathrm{rd}=1.18,1 \mathrm{st}=1.07 \%$ per min disappearance.

\section{Oral glucose tolerance test}

Prior to 1987 this test was performed with a $1 \mathrm{~g}$ per pound up to $100 \mathrm{~g}$ of oral glucose for children, and adults received $100 \mathrm{~g}$ of oral glucose. Subsequently, children receive $1.75 \mathrm{~g} / \mathrm{kg}$ of ideal body weight of oral glucose and adults $75 \mathrm{~g}$.

\section{Results}

Eighteen of the 35 ICA positive relatives have progressed to overt diabetes (Table 1). Fifteen of the 18 who have progressed to diabetes had $1+3 \mathrm{~min}$ IVGTT insulin response on one or more tests below the 1st percentile. One individual (patient 13, Table 2) who progressed to overt diabetes without a documented IVGTT ever below the 1st percentile, had his last IVGTT (at the 9th percentile) three years prior to overt diabetes, while of note patients 17 and 18 with normal $1+3$ min insulin on the last IVGTTs prior to diabetes had their last IVGTT seven months and one year prior to overt diabetes. To date, 15 of 
P. Vardi et al.: IVGTT in ICA + relatives

Table 2. Patients who progressed to overt diabetes

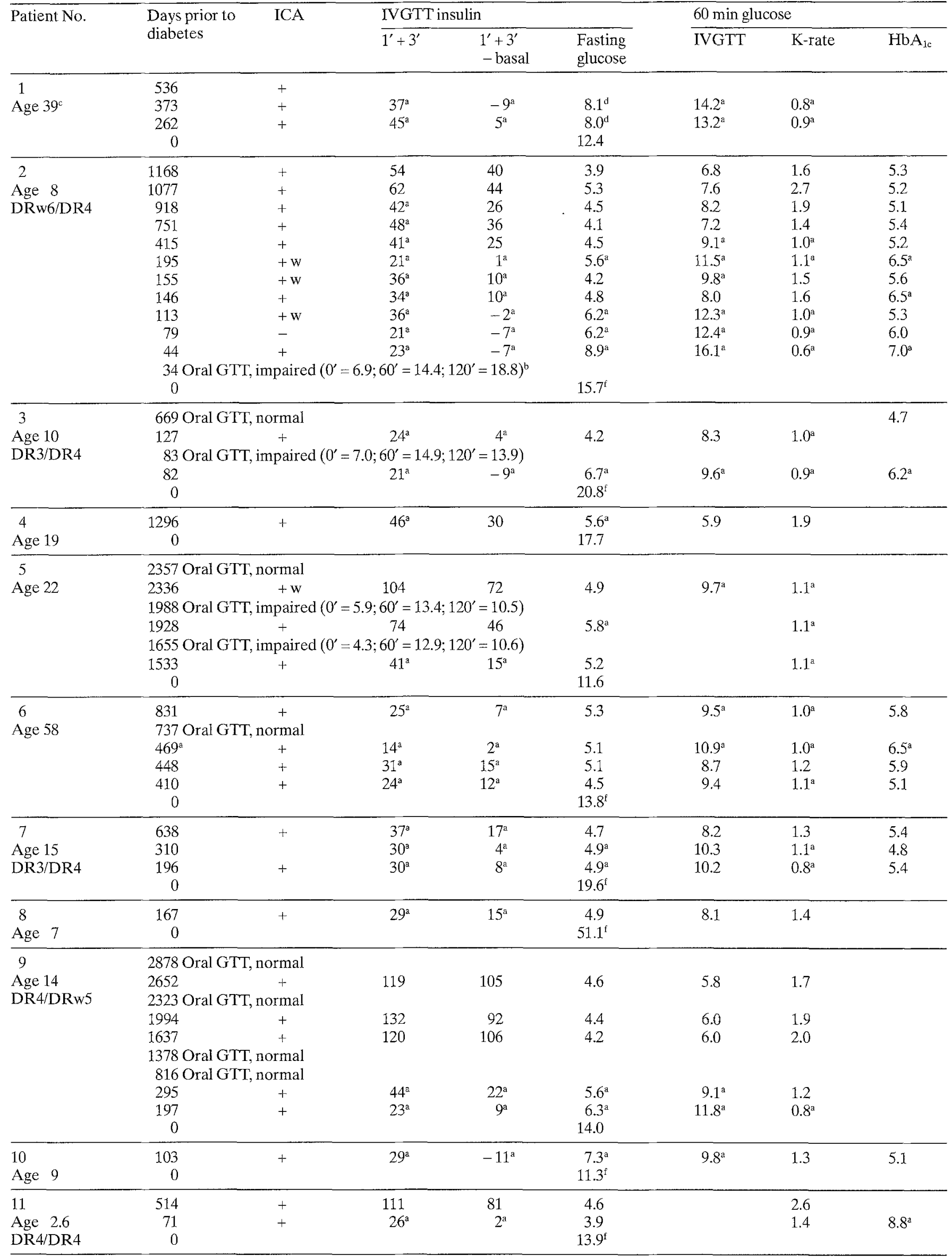


Table 2. (Continued)

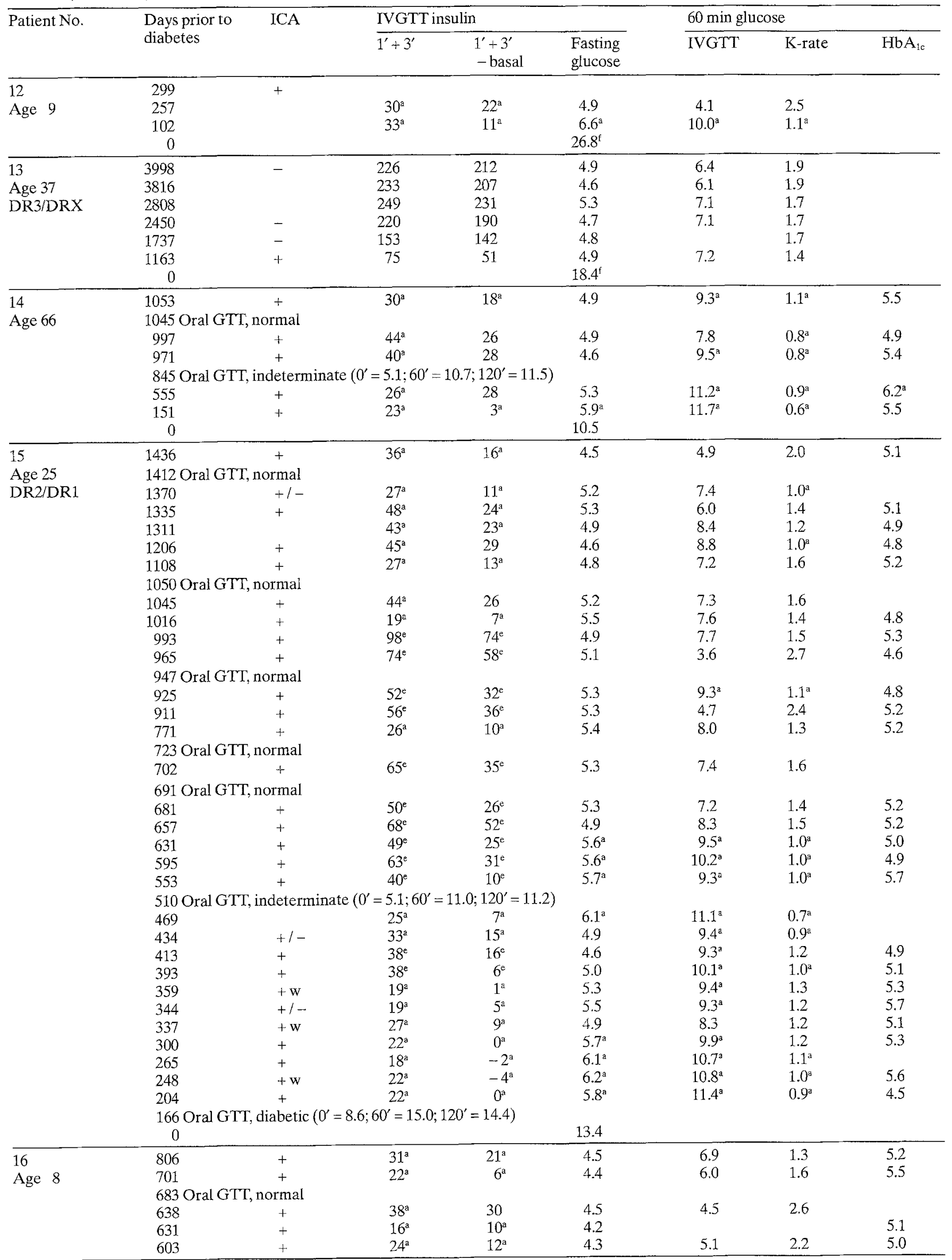


Table 2. (Continued)

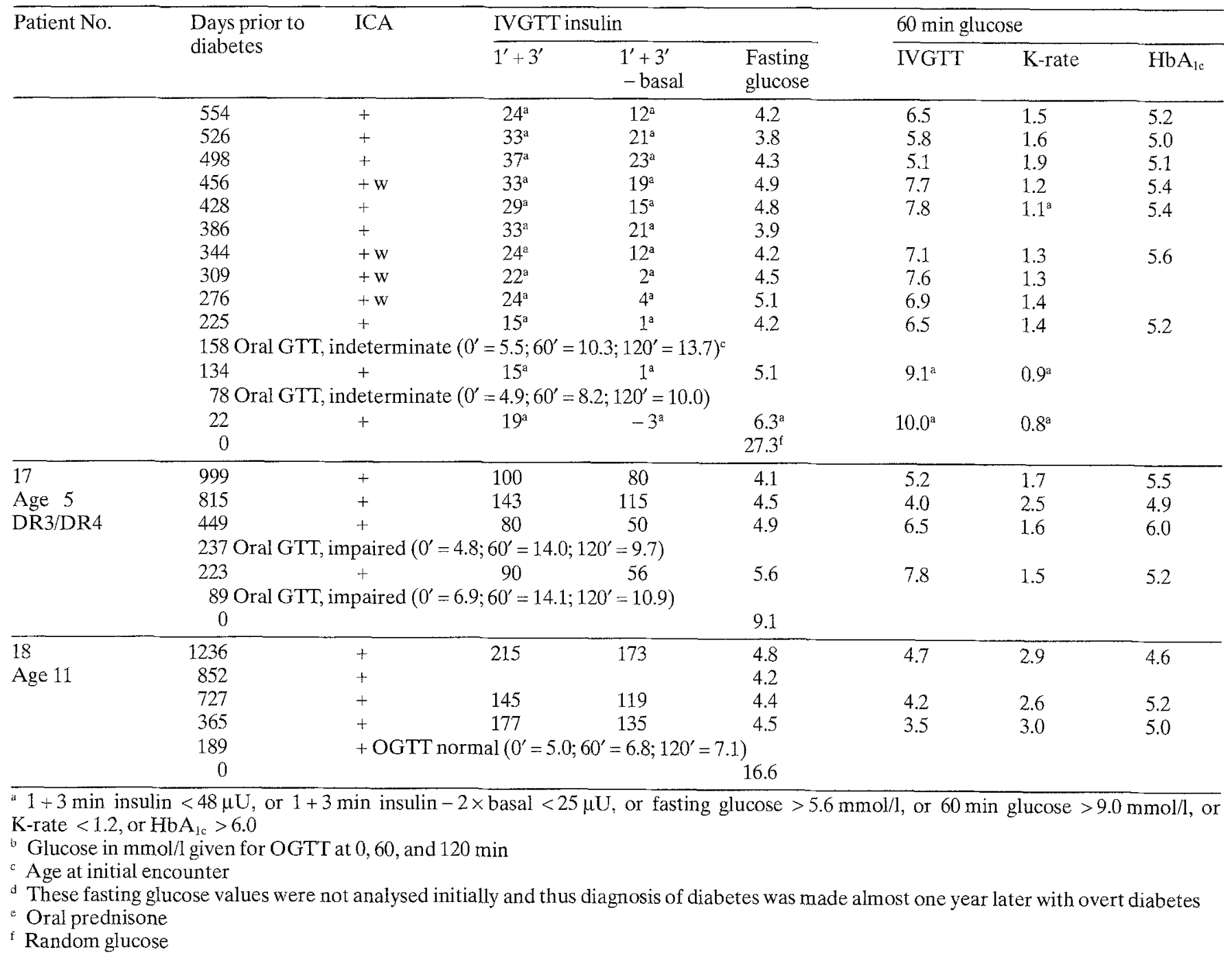

the $17(88 \%)$ relatives having an IVGTT below the 1 st percentile progressed to overt diabetes while only 3 of 18 $(17 \%)$ without detection of such a loss of IVGTT response progressed to diabetes. Amongst ICA positive relatives with an average 1,300 days of follow-up from the 1st encounter, the relative risk of progressing to overt diabetes with an IVGTT ever below the 1st percentile in contrast to IVGTTs always greater than the 1st percentile is 38 $(p<0.001$, Fisher's Exact Test), giving a positive predictive value of $88 \%$, a negative predictive value of $83 \%$, and a false negative rate of $17 \%$ (Table 1 ). If only the results of the initial IVGTT are utilized to categorize patients (IVGTTs greater than or less than 1st percentile), then of those below the 1st percentile at initial IVGTT 11 of 11 have become diabetic, and of those greater than the 1st percentile at initial IVGTT 7 of 24 became diabetic, giving a positive predictive value of $100 \%$, and negative predictive value of $71 \%$.

Analysing incidence rates for diabetes development with IVGTTs below or above the 1st percentile, the in cidence of diabetes developing during follow-up when a patient has had an IVGTT below the 1st percentile is 0.48 per patient year of follow-up and 0.05 per year during fol- low-up with the last IVGTT above the 1st percentile ( $x^{2}$ $p<0.005$, Table 1 ).

Figure 1 presents life table analysis of progression to overt diabetes from the date of initial encounter. Life table analysis is given for all patients (middle line) and for those with initial IVGTT greater than or less than the 1st percentile. The more rapid progression to overt diabetes of those with loss of 1st phase insulin secretion at initial IVGTT is readily apparent (Wilcoxon Test for comparing life tables, $p<0.001$, $>1$ st percentile vs $<1$ st percentile). At 4 years of follow-up, life table predicted survival nondiabetic is $58.3 \pm 9.7 \%$ for all relatives ( $\pm 1 \mathrm{SD}$ ), $9.1 \pm 17.8 \%$ for those below the 1 st percentile and $83.1 \pm 10.3 \%$ for those initially greater than the 1st percentile. From the life table analysis (Fig.1) and the data presented in Table 3 , it is evident that the follow-up of many individuals with IVGTT response greater than the 1st percentile exceeds the time from initial evaluation to overt diabetes for the majority of currently diabetic individuals. In pre-diabetic patients once the IVGTT reached the 1st percentile there was little variability [none reaching the $1 \mathrm{st}$ percentile $(1+3 \mathrm{~min}$ insulin $=48 \mu \mathrm{U} / \mathrm{ml})$ had a subsequent IVGTT with $1+3$ min insulin exceeding 


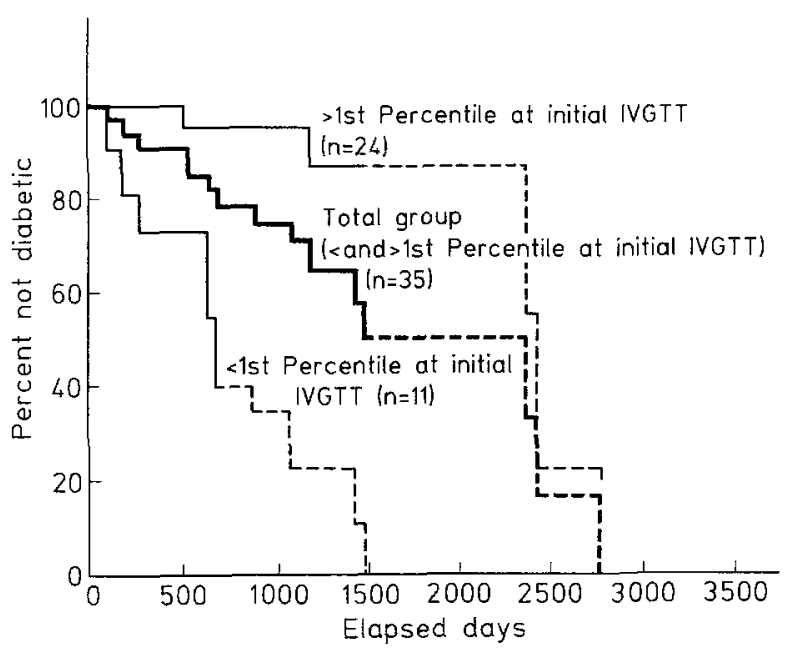

Fig. 1. Life table analysis of the development of overt diabetes for ICA positive relatives without their initial IVGTT $1+3 \mathrm{~min}$ insulin less than the 1st percentile (upper line) in contrast to ICA positive relatives initial $1+3$ min insulin on IVGTT less than the 1 st percentile $(48 \mu \mathrm{U} / \mathrm{ml})$ (lower line). Middle line is life table analysis for all patients combined. Elapsed days ( $\mathrm{x}$-axis) is from initial encounter with each patient

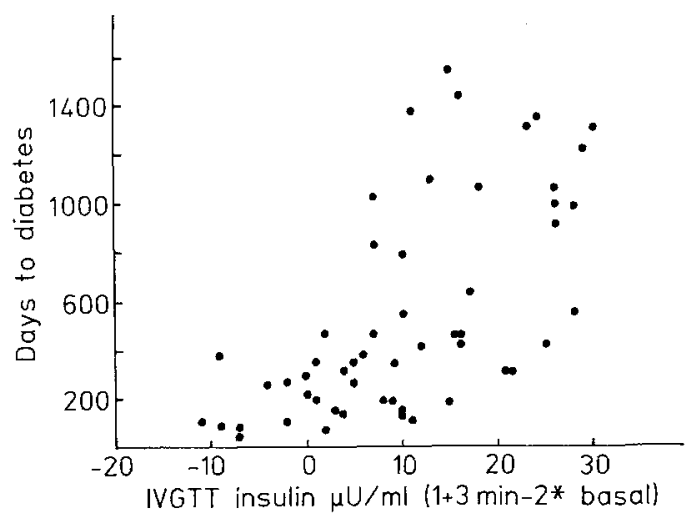

Fig. 2. Correlation of iv glucose stimulated 1 st phase insulin secretion vs days to overt diabetes. All insulin responses below the 1 st percentile of our relatives are plotted subtracting basal insulin, for IVGTT's total (not subtracting basal) where the $1+3 \mathrm{~min}$ insulin was less than the 1 st percentile $(48 \mu \mathrm{U} / \mathrm{ml})$. Because $2 *$ basal insulin is subtracted the highest $\mathrm{x}$-axis value is $30 \mu \mathrm{U} / \mathrm{ml}$ corresponding in this patient to $1+3 \mathrm{~min}$ insulin of $46 \mu \mathrm{U} / \mathrm{ml}$

$98 \mu \mathrm{U} / \mathrm{ml}]$ (Table 2). The mean time to development of overt diabetes from the initial IVGTT found to be below the 1st percentile was 656 days with a range of 71 to 1,543 days. Table 3 gives sequential $1+3$ min IVGTT values for the ICA positive relatives who have not progressed to overt diabetes, the 1 st two of whom have insulin secretion below the 1st percentile (patients 19 and 20, Table 3).

In contrast to $1+3 \mathrm{~min}$ insulin, other parameters (Tables 2 and 3 ) on the IVGTTs gave lower relative risks (RR) for development of diabetes (e.g., fasting glucose $>5.6 \mathrm{mmol} / \mathrm{l}, \mathrm{RR}=3.8 ; \mathrm{K}$-rate $<1.2, \mathrm{RR}=3.5$; glucose at $60 \mathrm{mins}>9.0 \mathrm{mmol} / \mathrm{l} ; \mathrm{RR}=4.0)$. The false negative rate for fasting glucose $>5.6 \mathrm{mmol} / \mathrm{l}$ was $39 \%$ ( 7 of 18 had glucose $\leq 5.6 \mathrm{mmol} / \mathrm{l}$ on all IVGTT's prior to diabetes), $38 \%$ for $\mathrm{K}$-rate $<1.2$ and $35 \%$ for glucose at
$60 \mathrm{~min}$ on IVGTT $>9.0 \mathrm{mmol} / \mathrm{l}$. By National Diabetes Data Group (NDDG) criteria the diagnosis of diabetes on an oral glucose tolerance test (OGTT) in children requires fasting glucose greater than $7.8 \mathrm{mmol} / \mathrm{l}$ and therefore patients 2 and 3 (Table 2) had impaired glucose tolerance rather than diabetes 34 and 83 days respectively prior to the diagnosis of overt diabetes. Patients $6,14,15$ and 16 (Table 2) were documented as having normal OGTT after 1st phase insulin secretion was found to be less than the 1st percentile. It is of interest that four adult patients had K-rates of 0.9 to 1.1 at a time their 1st phase insulin secretion exceeded the 1st percentile (patient 5, age 22; patient 19 , age 33 ; patient 20 , age 25 and patient 25 , age 52). Four of these four also had indeterminate OGTTs by NDDG criteria. For three of the patients, glucose stimulated insulin release above basal $(1+3 \mathrm{~min}$ insulin $-2 \times$ fasting insulin) was below the 5 th percentile of normal subjects but for patient 5 , IVGTT insulin release was approximately the 20 th percentile.

As illustrated in Figure 2 the value of glucose stimulated insulin secretion, plotted for values below the 1st percentile of relatives who have progressed to diabetes correlates with the time to overt diabetes $(r=0.586$, $p<0.001$ ). In this figure the basal insulin has been subtracted from the $1+3 \mathrm{~min}$ insulin $(1+3 \mathrm{~min}$ insulin $2 \times$ fasting insulin) to reflect only glucose stimulated insulin secretion.

\section{Discussion}

In our ICA positive relatives, we find loss of IVGTT insulin response aids in assessing risk of progression to overt diabetes. In ICA positive relatives with 1st phase insulin secretion ever below the 1 st percentile the relative risk (odds ratio) of progressing to overt diabetes is with approximately 4 years of follow-up 38 [positive predictive value $88 \%$, negative predictive value $83 \%$, overall accuracy $86 \%$, false negatives $17 \%$ ( 3 of 18 ) and false positives $12 \%$ with current duration of follow-up]. Fasting glucose, glucose at $60 \mathrm{~min}$ on IVGTT and K-rate on IVGTT are poorer predictors of progression to overt diabetes primarily due to higher false negative rates. (False negatives: Krate $<1.2=45 \%$, fasting glucose $>5.6 \mathrm{mmol} / 1=39 \%$, and $60 \mathrm{~min}$ IVGTT glucose $>9.0 \mathrm{mmol} / \mathrm{l}=35 \%$ ). In part the higher false negative rate for glucose on IVGTT compared to $1+3$ min insulin probably reflects the temporally later development of glucose abnormalities as contrasted with IVGTT insulin below the 1st percentile. If studies are performed frequently enough it is likely that elevations in glucose will more often be detected prior to overt diabetes.

The profound loss of insulin secretion on IVGTT can precede overt diabetes by years and in the current study preceded overt diabetes by an average of 656 days. This average almost certainly underestimates the mean length of time that loss of 1 st phase secretion precedes diabetes in that the initial IVGTT, at the time islet cell antibodies were discovered, was below the 1st percentile of 11 of the 15 currently diabetic patients in whom IVGTT less than the 1 st percentile was documented. It is noteworthy that 
Table 3. Patients non-diabetic ${ }^{e}$ at last follow-up

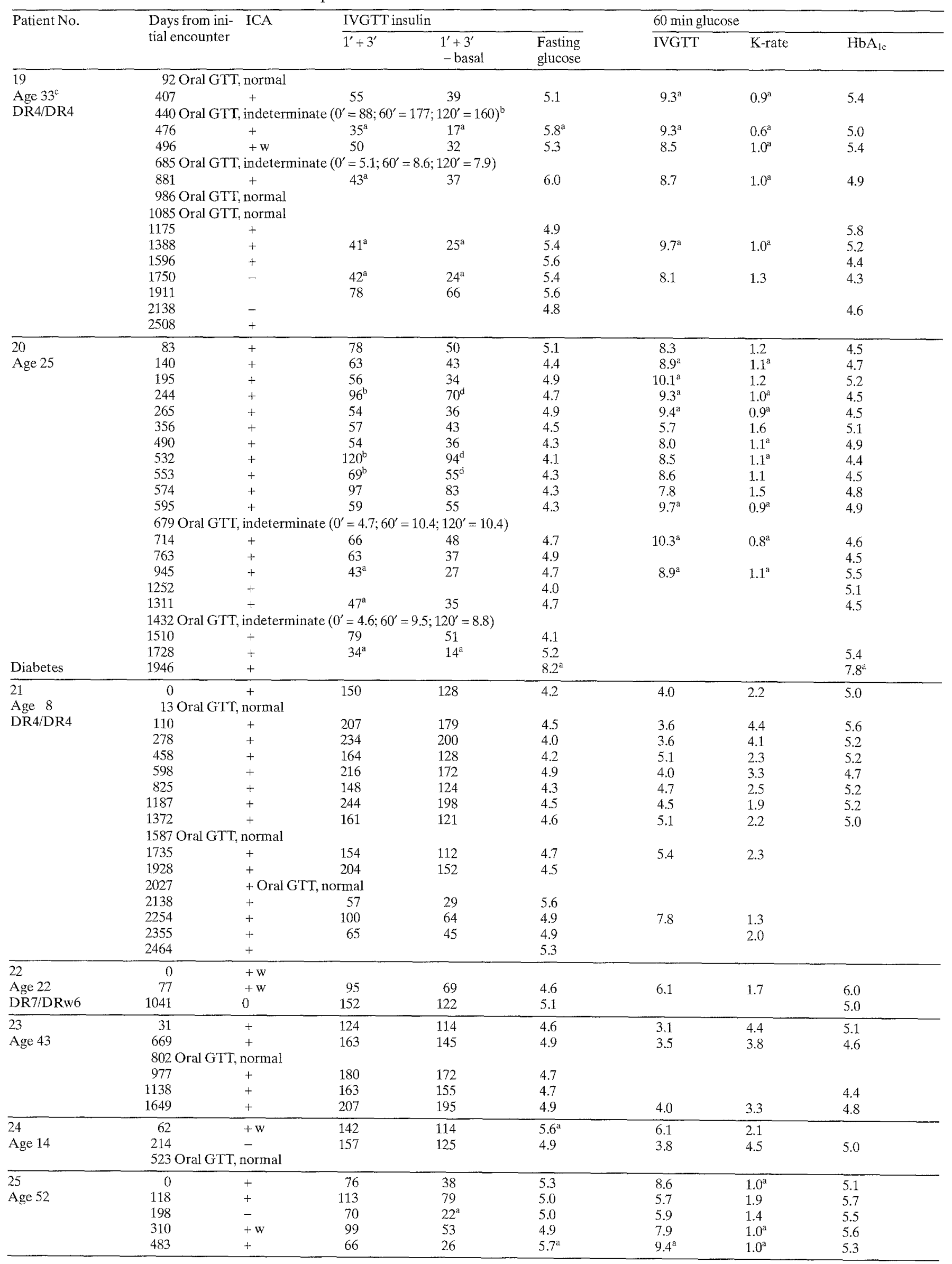


Table 3. (Continued)

\begin{tabular}{|c|c|c|c|c|c|c|c|c|}
\hline \multirow[t]{2}{*}{ Patient No. } & \multirow{2}{*}{$\begin{array}{l}\text { Days from ini- } \\
\text { tial encounter }\end{array}$} & \multirow[t]{2}{*}{$\mathrm{ICA}$} & \multicolumn{3}{|c|}{ IVGTT insulin } & \multicolumn{3}{|c|}{60 min glucose } \\
\hline & & & $\overline{1^{\prime}+3^{\prime}}$ & $\begin{array}{l}1^{\prime}+3^{\prime} \\
- \text { basal }\end{array}$ & $\begin{array}{l}\text { Fasting } \\
\text { glucose }\end{array}$ & IVGTT & K-rate & $\mathrm{HbA}_{\mathrm{lc}}$ \\
\hline & $\begin{array}{l}672 \text { Oral GTI } \\
1085 \\
1303\end{array}$ & $\begin{array}{l}\text { indete } \\
- \\
-\end{array}$ & $\begin{array}{c}0^{\prime}=5.3 \\
79 \\
123\end{array}$ & $\begin{array}{c}6 ; 120^{\prime}=1 \\
27 \\
13^{\mathrm{a}}\end{array}$ & $\begin{array}{l}5.5 \\
5.7^{\mathrm{a}}\end{array}$ & $\begin{array}{l}9.6^{\mathrm{a}} \\
8.1\end{array}$ & $\begin{array}{l}1.1^{\mathrm{a}} \\
1.4\end{array}$ & 5.8 \\
\hline $\begin{array}{l}26 \\
\text { Age } 30\end{array}$ & $\begin{array}{l}56 \\
1157 \\
1423 \text { Oral GTT }\end{array}$ & $\begin{array}{l}+ \\
+ \\
\text { diabet }\end{array}$ & $\begin{array}{r}174 \\
91 \\
3 ; 60^{\prime}=\end{array}$ & $\begin{array}{c}148 \\
61 \\
=11.4)\end{array}$ & $\begin{array}{l}5.3^{\mathrm{a}} \\
6.3^{\mathrm{a}}\end{array}$ & $13.7^{\mathrm{a}}$ & $\begin{array}{l}0.9^{\mathrm{a}} \\
0.9^{\mathrm{a}}\end{array}$ & \\
\hline $\begin{array}{l}27 \\
\text { Age } 47\end{array}$ & $\begin{array}{r}0 \\
105 \\
644 \\
1022\end{array}$ & $\begin{array}{l}+w \\
- \\
-\end{array}$ & $\begin{array}{l}105 \\
108 \\
226\end{array}$ & $\begin{array}{r}83 \\
80 \\
180\end{array}$ & $\begin{array}{l}6.3^{\mathrm{a}} \\
4.8\end{array}$ & $\begin{array}{c}10.7^{\mathrm{a}} \\
7.8\end{array}$ & $\begin{array}{l}0.72^{\mathrm{a}} \\
1.3\end{array}$ & \\
\hline $\begin{array}{l}28 \\
\text { Age } 8 \\
\text { DR4/DR3 }\end{array}$ & $\begin{array}{r}0 \\
29 \\
568 \\
1114 \\
1450 \\
1482\end{array}$ & $\begin{array}{l}+ \\
+ \\
+ \\
+ \\
+ \\
+ \text { Ora }\end{array}$ & $\begin{array}{c}88 \\
71 \\
56 \\
61 \\
\text { rmal }\end{array}$ & $\begin{array}{l}72 \\
59 \\
42 \\
35\end{array}$ & $\begin{array}{l}4.9 \\
4.9 \\
5.1 \\
5.8^{\mathrm{a}}\end{array}$ & $\begin{array}{l}5.7 \\
3.8\end{array}$ & $\begin{array}{l}2.1 \\
3.2\end{array}$ & $\begin{array}{l}5.1 \\
4.5 \\
4.8 \\
4.9\end{array}$ \\
\hline $\begin{array}{l}29 \\
\text { Age } 11\end{array}$ & $\begin{array}{r}0 \\
45 \\
207 \\
374 \\
586 \\
768 \\
1146 \\
1298 \\
1321 \\
1323 \\
1342\end{array}$ & $\begin{array}{l}+ \\
+ \\
+ \\
+ \\
+ \\
+ \\
+ \\
+ \\
+ \text { Ora } \\
+\end{array}$ & $\begin{array}{r}104 \\
61 \\
60 \\
120 \\
108 \\
129 \\
42^{\mathrm{a}} \\
38^{\mathrm{a}} \\
\mathrm{rmal} \\
38^{\mathrm{a}}\end{array}$ & $\begin{array}{r}88 \\
61 \\
48 \\
\\
94 \\
113 \\
28 \\
24^{\mathrm{a}} \\
24^{\mathrm{a}}\end{array}$ & $\begin{array}{l}4.9 \\
5.7^{\mathrm{a}} \\
5.2 \\
5.1 \\
5.0\end{array}$ & & & \\
\hline $\begin{array}{l}30 \\
\text { Age } 34\end{array}$ & $\begin{array}{l}21 \\
494 \\
823 \text { Oral GTT } \\
1062\end{array}$ & $\begin{array}{l}+ \\
+ \\
\text { norma } \\
-\end{array}$ & $\begin{array}{l}139 \\
235 \\
251\end{array}$ & $\begin{array}{l}127 \\
215 \\
237\end{array}$ & $\begin{array}{l}4.9 \\
4.6 \\
4.9\end{array}$ & $\begin{array}{l}6.6 \\
5.8\end{array}$ & $\begin{array}{l}2.0 \\
2.5\end{array}$ & $\begin{array}{l}6.1^{\mathrm{a}} \\
5.8\end{array}$ \\
\hline $\begin{array}{l}31 \\
\text { Age } 50^{c} \\
\text { DR2/DR1 }\end{array}$ & 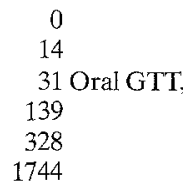 & $\begin{array}{l}+ \\
+ \\
\text { norma } \\
+ \\
+\end{array}$ & $\begin{array}{l}161 \\
177 \\
112 \\
154\end{array}$ & $\begin{array}{r}137 \\
\\
153 \\
98 \\
138\end{array}$ & $\begin{array}{l}4.9 \\
5.2 \\
5.4 \\
5.0\end{array}$ & $\begin{array}{l}5.2 \\
6.1 \\
5.5\end{array}$ & $\begin{array}{l}2.0 \\
\\
2.3 \\
1.7\end{array}$ & $\begin{array}{l}5.5 \\
6.0^{\mathrm{a}} \\
6.1^{\mathrm{a}}\end{array}$ \\
\hline $\begin{array}{l}32 \\
\text { Age } 39\end{array}$ & $\begin{array}{r}0 \\
319 \\
830\end{array}$ & $\begin{array}{l}+ \\
+ \\
+\end{array}$ & $\begin{array}{r}86 \\
235 \\
71\end{array}$ & $\begin{array}{r}62 \\
181 \\
55\end{array}$ & $\begin{array}{l}5.3 \\
5.0 \\
5.1\end{array}$ & $\begin{array}{l}6.5 \\
4.5\end{array}$ & $\begin{array}{l}1.8 \\
4.4\end{array}$ & $\begin{array}{l}6.0 \\
5.2 \\
4.9\end{array}$ \\
\hline $\begin{array}{l}33 \\
\text { Age 10 } \\
\text { DR3/DR3 }\end{array}$ & $\begin{array}{c}0 \\
7 \text { Oral GTT } \\
143 \\
318 \\
715 \\
988 \\
1325 \\
1809\end{array}$ & $\begin{array}{l}+ \\
\text { norma } \\
+1- \\
+ \\
+ \\
+ \\
+ \\
+\end{array}$ & $\begin{array}{l}184 \\
\\
245 \\
344 \\
154 \\
384 \\
494 \\
282\end{array}$ & $\begin{array}{l}154 \\
207 \\
310 \\
140 \\
322 \\
412 \\
280\end{array}$ & $\begin{array}{l}4.9 \\
4.9 \\
4.4 \\
4.9 \\
5.2 \\
5.1\end{array}$ & $\begin{array}{l}4.8 \\
3.9 \\
7.3 \\
5.9 \\
4.5\end{array}$ & $\begin{array}{l}2.1 \\
3.5 \\
1.7 \\
2.1 \\
3.0 \\
2.0\end{array}$ & $\begin{array}{l}4.1 \\
4.7\end{array}$ \\
\hline $\begin{array}{l}34 \\
\text { Age } 8 \\
\text { Diabetes }\end{array}$ & $\begin{array}{r}109 \\
229 \\
369 \\
1293 \\
1650\end{array}$ & $\begin{array}{l}+ \\
- \\
+ \\
+\end{array}$ & $\begin{array}{r}101 \\
65 \\
56 \\
133\end{array}$ & $\begin{array}{r}81 \\
53 \\
44 \\
109\end{array}$ & $\begin{array}{c}4.6 \\
5.5 \\
5.4 \\
4.7 \\
16.5 \mathrm{f}\end{array}$ & 8.1 & $\begin{array}{l}1.4 \\
2.1 \\
1.6\end{array}$ & \\
\hline $\begin{array}{l}35 \\
\text { Age } 40\end{array}$ & $\begin{array}{r}0 \\
56 \\
287 \\
1549\end{array}$ & $\begin{array}{l}+ \\
+ \\
- \\
-\end{array}$ & $\begin{array}{l}203 \\
194 \\
227\end{array}$ & $\begin{array}{l}181 \\
174 \\
211\end{array}$ & $\begin{array}{l}4.7 \\
4.2 \\
4.2\end{array}$ & 7.0 & $\begin{array}{l}2.2 \\
2.4\end{array}$ & $\begin{array}{l}6.0 \\
5.8\end{array}$ \\
\hline
\end{tabular}

a $1+3 \mathrm{~min}$ insulin $<48 \mu \mathrm{U} / \mathrm{ml}$, or $1+3 \mathrm{~min}-2 \times$ basal insulin $<25 \mu \mathrm{U} / \mathrm{ml}$, or fasting glucose $>5.6 \mathrm{mmol} / 1$, or glucose $60 \mathrm{~min}$ IVGTT $>9.0 \mathrm{mmol} / 1$, or K-rate $<1.2$, or $\mathrm{HbA}_{1 c}>6.0$

b Glucose in $\mathrm{mmol} / \mathrm{l}$ given for OGTT at 0,60 , and $120 \mathrm{~min}$

c Age at initial encounter

- Oral prednisone

Patients 20,26, and 34 developed diabetes after manuscript submission and analysis

f random glucose 
the absolute insulin secretion even below the 1st percentile correlates with the time to development of overt diabetes (Fig. 2). Insulin secretion can vary both with puberty, insulin resistance and marked obesity [12]. It is also important to note that loss of 1 st phase insulin secretion is not an abnormality specific to Type 1 diabetes but occurs with Type 2 diabetes [13] and following partial pancreatectomy [14].

The current analysis of predictive value of IVGTT response in ICA positive relatives was performed with an average of approximately 1,300 days of follow-up. We have observed a relative (patient 9, Table 2) in whom 1st phase insulin secretion was lost after 1,300 days of follow-up (2,583 days from initial encounter) and who then progressed to diabetes. It is likely that with longer follow-up, more of the relatives currently above the 1st percentile will lose 1st phase secretion and progress to diabetes. With our current serial IVGTT we hope not to miss such conversion prior to overt diabetes as we probably did in the one relative (patient 13, Table 2) whose last IVGTT was at the ninth percentile 3 years prior to overt diabetes. Nevertheless, as patients 17 and 18 illustrate, IVGTT's at 3 month intervals may be required in a subset of children. These two children are important exceptions to documented loss of IVGTT prior to diabetes having $1+3 \mathrm{~min}$ insulin response above the 1 st percentile 7 months and 1 year prior to diabetes. Of the two currently non-overtly diabetic ICA positive relatives whose 1st phase insulin secretion is now below the 1st percentile only one (patient 19, Table 3 ) at the latest follow-up has normal oral glucose tolerance by NDDG criteria.

Analysis of the predictive value of the IVGTT response below the 1st percentile should not be extended to ICA negative "non-relatives" or even ICA positive nonrelatives. There is little long-term data concerning ICA"normal" individuals with $1+3 \mathrm{~min}$ insulin secretion below the 1 st percentile. By definition $1 \%$ of normal individuals are at or below the 1 st percentile. To date we have followed one such normal individual (without a family history of diabetes) for 21 years. Although his 1st IVGTT was below the 1st percentile (subsequent IVGTT's between the 2 nd and 5th percentiles) he has not developed diabetes or glucose intolerance and is currently age 60 . In the normal individuals we have followed, ICA negative identical twins of Type 1 diabetic patients [15], and ICA positive relatives with 1 st phase insulin secretion above the 5 th percentile (Table 3 ) there is variation of $1+3 \mathrm{~min}$ insulin within the normal range.

Recent analysis of the Barts-Windsor study indicates that of the two ICA assays employed in this study, a complement fixing ICA assay is highly predictive of the development of overt Type 1 diabetes [1]. In this same study [1], relatives ICA positive utilizing a fluorescein conjugated anti-antibody but negative by complement fixing ICA had a low risk of developing diabetes ( 1 of 33 ; not substantially different from ICA negative siblings). In an ICA workshop, the FITC-protein A ICA assay we employ [11] gave similar sensitivity in terms of dilution of sera assayed as positive as the Barts-Windsor complement fixing ICA assay (significantly lower titres positive when compared to most anti-IgG assays) [11]. A similar comparison of our FITC-protein A assay with the ICA assay utilized in the past in Gainesville (even though Gainesville employs a fluorescein conjugated anti-antibody) indicates that the two assays had a similar assay sensitivity $[3,11]$. These three functionally similar assays [Joslin: protein A, Barts-Windsor: complement fixing ICA, Gainesville: FITC anti-IgG ( $>40$ JDF units)] identify antibody positive relatives with a risk of approximately $8 \%$ per year of progressing to overt diabetes with eventual total risk beyond 6 years not known $[1,3,6]$. It is important to note that the current study has utilized an ICA assay with a high cutoff ( $>40$ JDF units) and high specificity ( $<1$ of 400 control subjects ICA positive) and the predictive values apply to relatives with a high titre of ICA. Since relatives are informed concerning their ICA results we have only used such assay formats. The predictive value of lower titres of ICA (<40 JDF units) where antibody positivity appears to fluctuate was not evaluated in this study. The current study evaluated ICA in terms of negatives and positives and thus fluctuation in titre would not have been detected.

Our findings concerning the predictive value of intravenous glucose tolerance testing in ICA positive relatives are in general agreement with those of Chase and co-workers [7] with, we believe, longer follow-up allowing us to identify adults as well as ICA positive children progressing to diabetes. In our study abnormalities of glucose tolerance can become evident (elevation in fasting glucose $>5.6 \mathrm{mmol} / \mathrm{l}, 60 \mathrm{~min}$ glucose on IVGTT $>9.0 \mathrm{mmol} / \mathrm{l}$, impaired glucose tolerance on OGTT, $\mathrm{HbA}_{1 \mathrm{c}}$ intermittently > 6.0) prior to overt diabetes. However, when an early enough IVGTT was available, loss of IVGTT insulin response $(<1$ st percentile) was usually documented as preceding these abnormalities. Our data indicate that a combination of ICA screening and intravenous glucose tolerance testing identifies relatives with a very high risk of progressing to overt diabetes. It is likely that other parameters will be identified to aid in predicting when an ICA positive 1st degree relative will develop overt diabetes. In particular we have preliminary evidence that measurement of insulin autoantibodies in combination with IVGTT may aid risk assignment and has led to a "dual parameter" linear-regression model to predict diabetes onset [16]. The ability to accurately predict Type 1 diabetes should facilitate development of therapies to prevent this disorder.

Acknowledgements. Additional co-authors are Drs. R.Dumont Herskowitz, J. I.Wolfsdorf, D. Einhorn, L.Linarelli, R. Dolinar, S. Wentworth, S.J.Brink, H.Starkman, J.S.Soeldner and G.S. Eisenbarth. We gratefully acknowledge the technical support of Ms. M. Tautkus, A. Rabizadeh and M. Grinbergs, the skilled nursing of Ms. T.M.Smith, R.N. and the secretarial assistance of Mrs. P. Cronin-Sevigny. This work was supported by grants from the National Institutes of Health (R01-DK32083, DK33790, DK 39233), Massachusetts Lions Eye Research Fund and Diabetes Endocrine Research Center Grant (1P30-DK36837) with core facilities. CRC CLINFO (Brigham and Women's Hospital) was used for data storage and analysis. Dr. Vardi was supported by the Adler Foundation. We thank Dr. J.Warram for advice concerning statistical analysis. 


\section{References}

1. Gale EAM, Bottazzo GF (1986) Can we predict Type I (insulindependent) diabetes? In: Krall L (ed) World book of diabetes in practice. Elsevier, The Netherlands, pp 25-29

2. Srikanta S, Ganda OP, Jackson RA, Gleason RE, Kaldany A, Garovoy MR, Milford EL, Carpenter CB, Soeldner JS, Eisenbarth GS (1983) Type I diabetes mellitus in monozygotic twins: chronic progressive beta cell dysfunction. Ann Int Med 99: 320326

3. Riley W, Maclaren N (1984) Islet cell antibodies are seldom transient. Lancet I: $1351-1352$

4. Srikanta S, Ganda OP, Jackson RA, Brink SJ, Fleischnick E, Yunis E, Alper C, Soeldner JS, Eisenbarth GS (1984) Pre-Type I diabetes: common endocrinologic course despite immunologic and immunogenetic heterogeneity. Diabetologia 27: 146-149

5. Eisenbarth GS, Fleischnick E, Ganda OP, Srikanta S, Jackson RA, Brink SJ, Soeldner JS, Yunis E, Alper C (1985) Progressive autoimmune beta cell insufficiency: occurrence in the absence of high risk HLA alleles DR3, DR4. Diab Care 8: 477-480

6. Srikanta S, Ganda OP, Soeldner JS, Eisenbarth GS (1985) First degree relatives of patients with Type I diabetes mellitus: islet cell antibodies and abnormal insulin secretion. NEngl J Med 313: 461-464

7. Chase HP, Vass MA, Butler-Simon N, Hoops S, O'Brien D, Dobersen MJ (1987) Diagnosis of pre-Type I diabetes. J Pediatr 111: $807-812$

8. Riley W, Maclaren NK, Spillar R, Krischer J, Silverstein J, Malone J, Schwartz S, MacMillam D, Rotter J (1988) Predictive value of ICA for IDD and insulopenia to IV glucose. Diabetes [Woods Hole Suppl]: 20A

9. Bottazzo GF, Pujol-Borrell R, Gale EAM (1987) Autoimmunity and Type I diabetes: bringing the story up to date. In: Alberti K, Krall L (eds) The Diabetes Annual 3. Elsevier, The Netherlands, pp 15-38
10. Srikanta S, Rabizadeh A, Omar MAK, Eisenbarth GS (1985) Assay for islet cell antibodies: protein A - monoclonal antibody method. Diabetes 34: 300-305

11. Boitard CH, Bonifacio E, Bottazzo GF, Gleichmann H, Molenaar J (1988) Immunology and Diabetes Workshop: Report of the Third International (Stage 3) Workshop on the Standardization of Cytoplasmic Islet Cell Antibodies. Diabetologia 31: 451-452

12. Smith CP, Williams AJK, Thomas JM, Archibald HR, Algar VD, Bottazzo GF, Gale EAM, Savage MO (1988) The pattern of basal and stimulated insulin responses to intravenous glucose in first degree relatives of Type 1 (insulin dependent) diabetic children and unrelated adults aged 5 to 50 years. Diabetologia 31: $430-434$

13. Seltzer HS, Allen EW, Herron AL, Brennan MT (1967) Insulin secretion response to glycemic stimulus: relations of delayed initial release to carbohydrate intolerance in mild diabetes mellitus. J Clin Invest 46: 323

14. Weir GC, Clore ET, Zmachinski CJ, Bonner-Weir S (1981) Islet secretion in a new experimental model for non-insulin dependent diabetes. Diabetes 30:590-595

15. Srikanta S, Ganda OP, Gleason RE, Jackson RA, Soeldner JS, Eisenbarth GS (1984) Pre-Type I diabetes: linear loss of beta cell response to intravenous glucose. Diabetes 33: 717-720

16. Jackson RA, Soeldner JS, Eisenbarth GS (1989) Testing the dual parameter model for predicting time to diabetes. Clin Res 37: 57/A

Received: 9 May 1990

G.S. Eisenbarth, M.D., Ph.D.

Joslin Diabetes Center

One Joslin Place

Boston, MA 02215

USA 